\title{
Characteristics of Sie Reuboh Supplemented with Different Combinations of Palm Vinegar (Arenga pinnata) and Kaffir Lime Leaves (Citrus hystrix)
}

\author{
Masyitah $^{a, *}$, I. I. Arief ${ }^{b}, \&$ T. Suryatic \\ aStudy Program of Animal Production and Technology, Graduate School, Bogor Agricultural University \\ bDepartment of Animal Production and Technology, Faculty of Animal Science, Bogor Agricultural University \\ Jalan Agatis, Kampus IPB Darmaga Bogor 16680, Indonesia. \\ (Received 10-04-2017; Reviewed 10-07-2017; Accepted 08-11-2017)
}

\begin{abstract}
This research was aimed to analyze the characteristics of sie reuboh processed with the addition of palm vinegar and kaffir lime leaves with different concentrations to produce sie reuboh with a good quality and to maintain the stability of its quality during storage at room temperature. The research consisted of 2 stages. In the first stage, $4000 \mathrm{~g}$ of sie reuboh was treated with different doses of palm vinegar and kaffir lime leaves $(0 \mathrm{~mL}$ and $0 \mathrm{~g}, 100 \mathrm{~mL}$ and $10 \mathrm{~g}, 120 \mathrm{~mL}$ and $20 \mathrm{~g}$, and $140 \mathrm{~mL}$ and $30 \mathrm{~g}$ ) for microbiological analysis. Sie reuboh with the best result of microbiological analysis was later used in Stage 2 to be stored at room temperature and was analyzed for its physical antioxidant activity, thiobarbituric acid reactive substance (TBARS), and microbiological analysis. The result showed that different levels of palm vinegar and kaffir lime leaves did not significantly affect the $a_{w^{\prime}} \mathrm{pH}$, yield, and microbiological characteristics of the sie reuboh. Different ratios of palm vinegar and kaffir lime leaves significantly affected $(\mathbf{P}<0.05)$ the tenderness of sie reuboh. Sie reuboh without addition of palm vinegar and kaffir lime leaves showed a better tenderness than sie reuboh added with palm vinegar and kaffir lime leaves. The best treatment based on microbiological analysis was shown by treatment of sie reuboh with $120 \mathrm{~mL}$ of palm vinegar and $20 \mathrm{~g}$ of kaffir lime leaves and this sie reuboh was later used to test the stability of the sie reuboh when it was stored at room temperature. The results showed that sie reuboh produced by addition of $120 \mathrm{~mL}$ of palm vinegar and $20 \mathrm{~g}$ of kaffir lime leaves demonstrated antioxidant activity for inhibition of free radicals as was indicated by the stability of TBARS value during 9 days of storage at room temperature. This combination of treatment could also effectively stabilize the quality of sie reuboh, as indicated by a proper storability at maximum limit of total plate count and mold growth until 3 days of storage at room temperature.
\end{abstract}

Keywords: sie reuboh, palm vinegar, kaffir lime leaves, storage room temperature

\section{ABSTRAK}

Tujuan penelitian adalah menganalisis karakteristik sie reuboh yang diberi penambahan cuka aren (Arenga pinnata) dan daun jeruk purut (Citrus hystrix) dengan konsentrasi berbeda untuk menghasilkan mutu sie reuboh yang baik dan mempertahankan stabilitas mutunya selama penyimpanan pada suhu ruang. Penelitian dilakukan dalam 2 tahap. Tahap 1 melakukan penambahan cuka aren dan daun jeruk purut yang berbeda $(0 \mathrm{~mL}$ dan $0 \mathrm{~g}, 100 \mathrm{~mL}$ dan $10 \mathrm{~g}, 120 \mathrm{~mL}$ dan $20 \mathrm{~g}$, serta $140 \mathrm{~mL}$ dan $30 \mathrm{~g})$. Perlakuan terbaik berdasarkan analisis mikrobiologi selanjutnya akan digunakan pada tahap 2 untuk disimpan pada suhu ruang dan dianalisa aktivitas antioksidan, thiobarbituric acid reactive substance (TBARS), dan analisis mikrobiologi. Hasil penelitian menunjukkan cuka aren dan daun jeruk purut dengan konsentrasi yang berbeda tidak menunjukkan pengaruh nyata pada $a_{w^{\prime}} \mathrm{pH}$, rendemen, dan karakteristik mikrobiologi. Cuka aren dan daun jeruk purut dengan rasio yang berbeda mempengaruhi $(\mathrm{p}<0.05)$ keempukan sie reuboh. Keempukan sie reuboh lebih baik tanpa penambahan cuka aren dan daun jeruk purut dibandingkan dengan penambahan cuka aren dan daun jeruk purut. Perlakuan terbaik berdasarkan analisis mikrobiologi ditunjukkan oleh pemberian $120 \mathrm{~mL}$ cuka aren dan $20 \mathrm{~g}$ daun jeruk purut yang kemudian diuji stabilitas pada penyimpanan suhu kamar. Sie reuboh hasil pengolahan dengan penambahan $120 \mathrm{~mL}$ cuka aren dan $20 \mathrm{~g}$ daun jeruk purut menunjukkan aktivitas antioksidan dalam menghambat radikal bebas yang ditandai dengan kemampuan mempertahankan nilai TBARS sampai hari ke-9 penyimpanan suhu ruang serta sudah efektif dalam menstabilkan mutu produk sie reuboh yang ditandai dengan kesesuaian batas maksimum total plate count dan kapang sampai hari ke-3 penyimpanan pada suhu ruang.

Kata kunci: sie reuboh, cuka aren, daun jeruk purut, penyimpanan suhu ruang

*Corresponding author:

E-mail: masyitah3181@gmail.com 


\section{INTRODUCTION}

Sie reuboh is a traditional food from Aceh, Indonesia, and processed from cow, sheep, or buffalo meat with addition of such ingredients as palm vinegar, fat, and spices. The meat was mixed with these ingredients and cooked to obtain a soft texture. The quality of meat processed with this traditional technique could be maintained and still acceptable for a month of storage at room temperature. The processed meat is reheated prior to consumption.

Palm vinegar is an important ingredient for preparation of sie reuboh, which contributes to a sour taste. This vinegar involves alcohol fermentation by Saccharomyces cerevisiae and acetic acid fermentation by Acetobacter aceti. The presence of acetic acid in palm vinegar is responsible for meat preservation. Acetic acid is effective to decontaminate molds and yeast as main targets in meat and its derivative products (ManiLopez et al. 2012). Antimicrobial activity of acetic acid is responsible for the presence of detrimental effects on microorganism through lowering of $\mathrm{pH}$ value (Theron \& Lues 2007).

Kaffir lime leaves are recognized to have antioxidant activities that are linked with the presence of essential oil, flavonoid, phenolic, saponin, steroid, terpenoid, alkaloid, and terpene (Rahmi et al., 2013). Lime peels and leaves are good sources of antioxidant compounds. Flavonoid is a phenolic compound reported to have a high antioxidant activity (Liciana et al., 2013). The use of preservative as natural antioxidant and antimicrobial source in meat products enhances the quality of meat product. Yuliani et al. (2011) studied antibacterial activity of essential oils from lime leaves and the result showed that the compound was able to induce inhibitory and lethal effects on Staphylococcus aureus and Escherichia coli. In addition, Widaningrum et al. (2015) found that the use of vinegar (processed from coconut water and banana peel) was able to extend the shelf life of chicken meat stored at room temperature through growth retardation of pathogenic bacteria such as Listeria monocytogenes. Thus, this study was aimed to analyze the characteristics of sie reuboh processed by addition of palm vinegar and kaffir lime leaves with different concentrations to produce a good quality of sie reuboh and to evaluate the stability of sie reuboh stored at room temperature.

\section{MATERIALS AND METHODS}

\section{Experimental Design}

The research cosisted of 2 stages. In the first stage, the sie reuboh was treated with different levels of palm vinegar and kaffir lime leaves (P0: $0 \mathrm{~mL}$ of palm vinegar and $0 \mathrm{~g}$ of kaffir lime leaves, P1: $100 \mathrm{~mL}$ of palm vinegar and $10 \mathrm{~g}$ of kaffir lime leaves, P2: $120 \mathrm{~mL}$ of palm vinegar and $20 \mathrm{~g}$ of kaffir lime leaves, and P3: $140 \mathrm{~mL}$ of palm vinegar and $30 \mathrm{~g}$ of kaffir lime leaves). The sie reubohes produced were measured their physical parameters i.e., $\mathrm{a}_{\mathrm{w}} \mathrm{pH}$, yield, and tenderness, as well as microbiological analysis i.e., total plate count, S. aureus, and E. coli. The data collected were expressed as means with standard of errors of at least 3 independent replications. Sie reuboh with the best microbiological parameters in Stage 1 were later tested for the stability of sie reuboh stored at room temperature in Stage 2. In Stage 2, the sie reuboh with the best microbiological parameters in Stage 1 were stored at room temperature and were analyzed for their physical antioxidant activities, thiobarbituric acid reactive substances (TBARS), and microbiological parameters.

\section{Preparation of Sie Reuboh}

Sie reuboh was prepared from $4000 \mathrm{~g}$ of knucle meat. Additional ingredients used were $20 \mathrm{~g}$ of ginger, $15 \mathrm{~g}$ of table salt, $20 \mathrm{~g}$ of fresh turmeric, $20 \mathrm{~g}$ of galangal, $15 \mathrm{~g}$ of onion, $25 \mathrm{~g}$ of fresh chili, $10 \mathrm{~g}$ of chili powder, 10 $\mathrm{g}$ of cayenne pepper, $300 \mathrm{~mL}$ of water, palm vinegar $(0$ $\mathrm{mL}, 100 \mathrm{~mL}, 120 \mathrm{~mL}$, and $140 \mathrm{~mL}$ ), and kaffir lime leaves $(0 \mathrm{~g}, 10 \mathrm{~g}, 20 \mathrm{~g}$, and $30 \mathrm{~g})$. The sie reuboh was produced with the following processes. The meat was cleaned, cut to $40-60 \mathrm{~g}$, washed, and drained for 5-10 min. All spices were pulverized, then mixed with water and meat. The mixture was cooked in a soil-made crock. After $15 \mathrm{~min}$, palm vinegar was added, and cooked for $45 \mathrm{~min}$. Kaffir lime leaves were then added and cooked to reduce water. The sie reuboh was treated with different levels of palm vinegar and kaffir lime leaves as follows: P0 $(0 \mathrm{~mL}$ of palm vinegar and $0 \mathrm{~g}$ of kaffir lime leaves), P1 (100 $\mathrm{mL}$ of palm vinegar and $10 \mathrm{~g}$ of kaffir lime leaves), P2 (120 $\mathrm{mL}$ of palm vinegar and $20 \mathrm{~g}$ of kaffir lime leaves), and P3 (140 mL of palm vinegar and $30 \mathrm{~g}$ of kaffir lime leaves).

\section{Physical Characteristics of Sie Reuboh}

$\mathrm{pH}$ of sie reuboh was determined in duplicate according to a direct probe by using $\mathrm{pH}$ meter (HANNA HI 99163 instrument, USA) following the method of Dominigue et al. (2015). The instrument was previously calibrated in buffer at $\mathrm{pH} 4$ and 7 . Water activity $\left(\mathrm{a}_{\mathrm{w}}\right)$ was determined by using $\mathrm{a}_{\mathrm{w}}$ meter Novasina (Novasina, Switzerland). Meat tenderness was measured by using texture analyzer TA-XT2i (Stable Micro System, UK) with company's protocol.

\section{Microbiological Analyses}

Twenty five grams of sie reuboh samples were dissolved in in $225 \mathrm{~mL}$ of buffer peptone water (BPW) solution and homogenized, then allowed to stand for $30 \mathrm{~min}$ to get a $10^{-1}$ dilution. As much as $1 \mathrm{~mL}$ of suspension of sie reuboh was pipette-transferred to get a $10^{-3}$ dilution. Population of total plate counts, E. coli, and S. aureus in the sie reuboh was determined according to BAM (2001). 
Total plate count (TPC). As much as $1 \mathrm{~mL}$ of sie reuboh suspension from $10^{-1}-10^{-3}$ dilutions was transferred into petridishes in duplicate, then added with $20 \mathrm{~mL}$ of Plate Count Agar (PCA) medium and homogenized. Then the petridishes filled with the mixture of PCA and sie reuboh suspension were incubated at $37^{\circ} \mathrm{C}$ for $36 \mathrm{~h}$.

E. coli. As much as $1 \mathrm{~mL}$ of sie reuboh suspension from $10^{-1}-10^{-3}$ dilutions were aseptic-pipetted into petridishes in duplicate, then added with $20 \mathrm{~mL}$ of Eosin Methylen Blue Agar (EMBA) medium and homogenized. The petridishes filled with the mixture of EMBA and sie reuboh suspension were incubated at $37^{\circ} \mathrm{C}$ for $36 \mathrm{~h}$.

S. aureus. As much as $1 \mathrm{~mL}$ of sie reuboh suspension from $10^{-1}-10^{-3}$ dilutions were aseptic-pipetted in duplicate into petridishes that were already filled with 15-20 $\mathrm{mL}$ of Baird Parker Agar (BPA) medium + egg yolk and homogenized. The suspension was then well-spread on the media surface using hockey stick and allowed to stand for $\pm 30 \mathrm{~min}$ at room temperature. The media were incubated upside down at $37^{\circ} \mathrm{C}$ for $36 \mathrm{~h}$.

\section{Antioxidant Activity Using DPPH Assay (Tangkanakul et al., 2009)}

Two grams of sie reuboh sample was extracted by 5 $\mathrm{mL}$ of methanol 100\% at room temperature for $24 \mathrm{~h}$ and filtered. The filtrate was transferred into another tube, and $5 \mathrm{~mL}$ of methanol was added. The filtrate solution was added by methanol to obtain a $10 \mathrm{~mL}$ of final volume. Antioxidant activity was determined by the scavenge ability of DPPH and the antioxidant capacity was determined by the scavenge ability of vitamin $C(0$, $0.5,1.0,1.5,2.0$, and $2.5 \mathrm{~mL} / \mathrm{mg}$ ) to scavenge DPPH. The solution was incubated for $20 \mathrm{~min}$, and the absorbance was detected at $517 \mathrm{~nm}$. Methanol was used for control. Inhibitory activity to DPPH was calculated as follow:

$\%$ Scavenging $=[(1-\mathrm{x}) / \mathrm{c}] \times 100 \%$

Note: $\mathrm{X}=$ absorbance of extract, $\mathrm{C}=$ absorbance of control

\section{Thiobarbituric Acid Reactive Substances (TBARS) (Sorensen \& Jorgensen, 1996)}

Standard curve was made from stock solution of 1,1,3,3-tetra oxypropane (TEP) $0.002 \mathrm{M}$ at concentrations of $2 \times 10^{-6} \mathrm{M}$ to $8 \times 10^{-6} \mathrm{M}$. Ten grams of minced sie reuboh sample was homogenized by adding $50 \mathrm{~mL}$ of distilled water containing $0.1 \%$ of propel galate (PG) and $0.1 \%$ of ethylene diamine tetraacetic acid (EDTA). The solution was transferred quantitatively into distillation tube by adding $47.5 \mathrm{~mL}$ of distilled water, $2.5 \mathrm{~mL}$ of $\mathrm{HCl} 4 \mathrm{~N}$, and 5 drops of antifoaming agent. The solution was distilled to obtain $50 \mathrm{~mL}$ of distillate for each sample. The distillate was incubated in waterbath at $100^{\circ} \mathrm{C}$ for $40 \mathrm{~min}$, and cooled. The absorbance was detected at wavelength of $532 \mathrm{~nm}$ using spectrophotometer. Each experiment was performed at duplicate. Malonaldehyde was calculated by using this formula:

Malonaldehyde content $(\mathrm{MD})=(\mathrm{CMDA} \times \mathrm{Vdes}) / \mathrm{Ms}$

Note: $\mathrm{CMDA}=$ Concentration of $\mathrm{MDA}$ as displayed in standart curve, Vdes= total destillate volume, Ms=Sample weight (g).

\section{Statistical Analysis}

The physical characteristics and microbiological properties of sie reuboh as a result of using various ratios of palm vinegar and kaffir lime leaves $(0 \mathrm{~mL}$ of palm vinegar and $0 \mathrm{~g}$ of kaffir lime leaves, $100 \mathrm{~mL}$ of palm vinegar and $10 \mathrm{~g}$ of kaffir lime leaves, $120 \mathrm{~mL}$ of palm vinegar and $20 \mathrm{~g}$ of kaffir lime leaves, and $140 \mathrm{~mL}$ of palm vinegar and $30 \mathrm{~g}$ of kaffir lime leaves) with experiment using group randomized design. Data of physical characteristics, antioxidant activity, TBARS, and microbiological properties during storage at room temperature were obtained by using a completely randomized design. The data were analyzed by using the analysis of variance (ANOVA) using Statistical Analysis System's Procedures (SAS) software. The significantly different treatments were further tested by Duncan's multiple range test.

\section{RESULTS}

\section{Characteristics of Sie Reuboh with Addition of Different Levels of Palm Vinegar (Arenga pinnata) and Kaffir Lime Leaves (Citrus hystrix)}

Physical characteristics observation showed that addition of palm vinegar and kaffir lime leaves during the process of sie reuboh production significantly decreased $(\mathrm{P}<0.05)$ the tenderness of sie reuboh without affecting $\mathrm{a}_{\mathrm{w}}, \mathrm{pH}$, and yield (Table 1). The tenderness of sie reuboh ranged from $3607.67 \pm 510.15$ gs to $6832.33 \pm$ 860.76 gs. Sie reuboh processed without addition of palm vinegar and kaffir lime leaves (P0) had the best tenderness (3606.67 $\pm 510.15 \mathrm{gs)}$ compared to those processed with the addition of palm vinegar and kaffir lime leaves. Even though it was not significant, the tenderness of sie reuboh decreased with the increased doses of palm vinegar and kaffir lime leaves used in the production. The tenderness of sie reuboh processed with the addition of $100 \mathrm{~mL}$ of palm vinegar and $10 \mathrm{~g}$ of kaffir lime leaves (P1), $120 \mathrm{~mL}$ of palm vinegar and $20 \mathrm{~g}$ of kaffir lime leaves (P2), and $140 \mathrm{~mL}$ of palm vinegar and 30

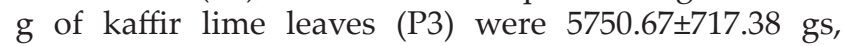
$6010.33 \pm 615.48 \mathrm{gs}$, and $6832.33 \pm 860.76 \mathrm{gs}$, respectively. The $a_{w}$ values of the sie reuboh were similar $(P>0.05)$ in all levels of palm vinegar and kaffir lime leaves addition and ranged from $0.831 \pm 0.01$ to $0.848 \pm 0.02$. The $\mathrm{pH}$ values of the sie reuboh were similar $(\mathrm{P}>0.05)$ in all levels of palm vinegar and kaffir lime leaves addition and ranged from $5.31 \pm 0.66$ to $5.86 \pm 0.33$. Similar to the $\mathrm{a}_{\mathrm{w}}$ and $\mathrm{pH}$ values, the yield values of sie reuboh were similar $(P>0.05)$ in all levels of palm vinegar and kaffir lime leaves addition and ranged from $47.79 \pm 1.24$ to $51.31 \pm 2$. Similar to the $\mathrm{a}_{\mathrm{w}}$ the $\mathrm{pH}$, and yield values, total plate counts were similar $(\mathrm{P}>0.05)$ in all levels of palm vinegar and kaffir lime leaves addition and ranged from $2.75 \pm 0.28 \mathrm{log} \mathrm{cfu} / \mathrm{g}$ to $3.44 \pm 0.72 \mathrm{log} \mathrm{cfu} / \mathrm{g}$. The colonies of Escherichia coli were detected at $<25$ colonies both in sie reuboh processed without palm vinegar and kaffir 
lime leaves addition (P0) (dilution 1) and those with addition of $100 \mathrm{~mL}$ of palm vinegar and $10 \mathrm{~g}$ of kaffir lime leaves (P1) (dilution 3). The colony of Escherichia coli was not detected in sie reuboh processed with the addition of $120 \mathrm{~mL}$ of palm vinegar and $20 \mathrm{~g}$ of kaffir lime leaves (P2) and $140 \mathrm{~mL}$ of palm vinegar and $30 \mathrm{~g}$ of kaffir lime leaves (P3). Additionally, colony of $S$. aureus was not detected in all treatments, both without and with palm vinegar and kaffir lime leaves additions.

\section{Characteristics Properties of Sie Reuboh during Storage at Room Temperature}

Based on microbiological analysis obtained in Stage 1 , sie reuboh processed with the addition of $120 \mathrm{~mL}$ of palm vinegar and $20 \mathrm{~g}$ of kaffir lime leaves (P2) exhibited the best quality, thus it was selected to be further observed in Stage 2. The sie reuboh processed with the addition of $120 \mathrm{~mL}$ of palm vinegar and $20 \mathrm{~g}$ of kaffir lime leaves (P2) were stored at room temperature (27$31^{\circ} \mathrm{C}$ ) for $9 \mathrm{~d}$.

During storage at room temperature, sie reuboh produced by addition of $120 \mathrm{~mL}$ of palm vinegar and $20 \mathrm{~g}$ of kaffir lime leaves (P2) showed significant differences $(\mathrm{P}<0.05)$ in $\mathrm{a}_{\mathrm{w}}$ antioxidant activity, antioxidant capacity, Thiobarbituric acid reactive substance (TBARS), and microbiological characteristics during 9 days of storage at room temperature (Table 2). However the sei reuboh produced by addition of of $120 \mathrm{~mL}$ of palm vinegar and $20 \mathrm{~g}$ of kaffir lime leaves (P2) did not show a significant change in $\mathrm{pH}$ during the 9 days of storage at room temperature. The $\mathrm{pH}$ value ranged from $4.94 \pm 0.04$ $5.28 \pm 0.45$ (Table 2).

The $\mathrm{a}_{\mathrm{w}}$ values of the sie reuboh produced by the addition of of $120 \mathrm{~mL}$ of palm vinegar and $20 \mathrm{~g}$ of kaffir lime leaves $(\mathrm{P} 2)$ significantly increased $(\mathrm{P}<0.05)$ when the sie reuboh were allowed and stored at room temperature for 3 and 6 days. However, at the stoage time of 9 days at room temperature, the $\mathrm{a}_{\mathrm{w}}$ values of the sie reuboh decreased $(\mathrm{P}<0.05)$ and returnd to the same level with those at the time of production (day 0) (Table 2).
Antioxidant activity and capcity of the sie reuboh produced by the addition of of $120 \mathrm{~mL}$ of palm vinegar and $20 \mathrm{~g}$ of kaffir lime leaves (P2) were similar that were high at the time of production (day 0) and decreased with the increase in the duration of storage at room temperature. The antioxidant activity and capacity of the sie reuboh produced by the addition of of $120 \mathrm{~mL}$ of palm vinegar and $20 \mathrm{~g}$ of kaffir lime leaves (P2) after 3 days of storage in room temperature slightly decreased $(\mathrm{P}>0.05)$ compared with that at the time of production (day 0). However, at the storage of 6 and 9 days, antioxidant activity and capacity of the sie reuboh produced by the addition of $120 \mathrm{~mL}$ of palm vinegar and $20 \mathrm{~g}$ of kaffir lime leaves $(\mathrm{P} 2)$ decreased significantly $(\mathrm{P}<0.05)$ compared to those at the time of production (day 0 ). There was no significant differences in antioxidant activity and capacity of the sie reuboh with the increased duration of storage to 9 days. Antioxidant activity of the sie reuboh processed by addition of $120 \mathrm{~mL}$ of palm vinegar and 20 $\mathrm{g}$ of kaffir lime leaves (P2) ranged from $33.93 \pm 2.16 \%$ (P3) to $53.34 \pm 2.33 \%$ (P0) (Table 2). Antioxidant capacity of the sie reuboh processed by addition of $120 \mathrm{~mL}$ of palm vinegar and $20 \mathrm{~g}$ of kaffir lime leaves (P2) ranged from 133.65 \pm 50.59 EVC mg $100 \mathrm{~g}^{-1}$ (P3) to 269.44 $\pm 39.02 \mathrm{EVC}$ mg $100 \mathrm{~g}^{-1}$ (P0).

Different from antioxidant capacity and activity, the values of thiobarbituric acid reactive substance (TBARS) of the sie reuboh processed by addition of 120 $\mathrm{mL}$ of palm vinegar and $20 \mathrm{~g}$ of kaffir lime leaves (P2) was low at the time of production (day 0) and significantly increased with the increased duration of storage at room temperature. The values of thiobarbituric acid reactive substance (TBARS) in the sie reuboh processed by addition of $120 \mathrm{~mL}$ of palm vinegar and $20 \mathrm{~g}$ of kaffir lime leaves (P2) increased significantly $(\mathrm{P}<0.05)$ at the storage duration of 3,6 , and 9 days at room temperature. However, the values of thiobarbituric acid reactive substance (TBARS) in the sie reuboh processed by addition of $120 \mathrm{~mL}$ of palm vinegar and $20 \mathrm{~g}$ of kaffir lime leaves (P2) were not significantly different at the storage duration of 3,6 , and 9 days $(P>0.05)$. The values

Table 1. Characteristics of sie reuboh with addition of different doses of palm vinegar (Arenga pinnata) and kaffir lime leaves (Citrus hystrix)

\begin{tabular}{|c|c|c|c|c|}
\hline \multirow{2}{*}{ Variables } & \multicolumn{4}{|c|}{ Treatments } \\
\hline & P0 & P1 & $\mathrm{P} 2$ & P3 \\
\hline \multicolumn{5}{|l|}{ Physical characteristics } \\
\hline aw & $0.848 \pm \quad 0.02$ & $0.838 \pm \quad 0.02$ & $0.835 \pm \quad 0.02$ & $0.831 \pm \quad 0.01$ \\
\hline $\mathrm{pH}$ & $5.860 \pm \quad 0.33$ & $5.500 \pm \quad 0.52$ & $5.390 \pm 0.56$ & $5.310 \pm 0.66$ \\
\hline Yield (\%) & $47.790 \pm 1.24$ & $49.290 \pm \quad 0.62$ & $49.500 \pm 1.61$ & $51.310 \pm \quad 2.86$ \\
\hline Tenderness $(g s)$ & $3607.670 \pm 510.15^{\mathrm{b}}$ & $5750.670 \pm 717.38^{a}$ & $6010.330 \pm 615.48^{a}$ & $6832.330 \pm 860.76^{\mathrm{a}}$ \\
\hline \multicolumn{5}{|l|}{ Microbiological properties } \\
\hline Total plate count (log cfu/g) & $3.440 \pm \quad 0.72$ & $2.850 \pm 1.13$ & $2.750 \pm \quad 0.28$ & $3.080 \pm 0.66$ \\
\hline E. coli* (colony) & $<25(1)$ & $<25(3)$ & nd & nd \\
\hline S. aureus*(colony) & nd & nd & nd & nd \\
\hline
\end{tabular}

Note: Means in the same row with different supercripts differ significantly $(\mathrm{P}<0.05)$; detection of $<2$ colonies in P0 at dilution 3 and in $\mathrm{P} 1$ at dilution 3 : nd= not detected (no colony observed). P0 (0 mL palm vinegar + 0 kaffir lime leaves), P1 (100 mL palm vinegar $+10 \mathrm{~g}$ kaffir lime leaves), P2 (120 $\mathrm{mL}$ palm vinegar $+20 \mathrm{~g}$ kaffir lime leaves) and P3 (140 $\mathrm{mL}$ palm vinegar $+30 \mathrm{~g}$ kaffir lime leaves). 
Table 2. Characteristics of sie reuboh stored at room temperature

\begin{tabular}{|c|c|c|c|c|}
\hline \multirow{2}{*}{ Variables } & \multicolumn{4}{|c|}{ Period of storage (Day) } \\
\hline & Day-0 & Day-3 & Day-6 & Day-9 \\
\hline \multicolumn{5}{|l|}{ Physical characteristics } \\
\hline aw & $0.837 \pm \quad 0.00^{\mathrm{b}}$ & $0.860 \pm 0.00^{\mathrm{a}}$ & $0.855 \pm 0.00^{\mathrm{a}}$ & $0.837 \pm 0.00^{\mathrm{b}}$ \\
\hline $\mathrm{pH}$ & $4.94 \pm \quad 0.04$ & $5.08 \pm 0.09$ & $5.10 \pm 0.07$ & $5.28 \pm 0.45$ \\
\hline Antioxidant activity (\%) & $53.34 \pm 2.33^{a}$ & $42.19 \pm 4.24^{\mathrm{ab}}$ & $37.29 \pm 10.08^{b}$ & $33.93 \pm 2.16^{b}$ \\
\hline $\begin{array}{l}\text { Antioxidant capacity (VCE mg/100 g DM } \\
\text { of sie reuboh) }\end{array}$ & $269.44 \pm 39.02^{\mathrm{a}}$ & $193.38 \pm 49.42^{\mathrm{ab}}$ & $136.53 \pm 80.46^{\mathrm{b}}$ & $133.65 \pm 50.59^{b}$ \\
\hline TBARS (mg MDA/kg DM of sie reuboh) & $0.66 \pm 0.04^{b}$ & $0.79 \pm 0.05^{\mathrm{a}}$ & $0.82 \pm 0.04^{\mathrm{a}}$ & $0.85 \pm 0.07^{a}$ \\
\hline \multicolumn{5}{|l|}{ Microbiolgical properties } \\
\hline Total plate count $(\log \mathrm{cfu} / \mathrm{g})$ & $3.15 \pm 0.58^{c}$ & $3.97 \pm 0.62^{\mathrm{bc}}$ & $4.69 \pm 0.24^{\mathrm{a}}$ & $4.84 \pm 0.21^{\mathrm{a}}$ \\
\hline Mold (log cfu/g) & $2.83 \pm \quad 0.21^{b}$ & $3.28 \pm 0.60^{\mathrm{b}}$ & $4.39 \pm 0.45^{\mathrm{a}}$ & $4.79 \pm 0.14^{\mathrm{a}}$ \\
\hline
\end{tabular}

Note: Means in the same row with different supercripts differ significantly $(\mathrm{P}<0.05)$.

of thiobarbituric acid reactive substance (TBARS) in the sie reuboh processed by addition of $120 \mathrm{~mL}$ of palm vinegar and $20 \mathrm{~g}$ of kaffir lime leaves (P2) ranged from $0.66 \pm 0.04$ in the beginning of storage (day 0 ) to $0.85 \pm 0.07$ $\mathrm{mg} \mathrm{MDA} / \mathrm{kg} 100^{-1} \mathrm{DM}$ at the storage duration of 9 days (Table 2).

Microbiological characteristics of the sie reuboh processed by addition of $120 \mathrm{~mL}$ of palm vinegar and $20 \mathrm{~g}$ of kaffir lime leaves (P2) as indicated by total plate count and mold showed the lowest values at the time of production (day 0) and increased with the increased duration of the storage. However, at the duration of 3 days of storage, the increase in total plate count and mold count was not significantly different $(\mathrm{P}>0.05)$. At the storage time of 6 and 9 days, the increases in total plate count and mold count were significantly different $(\mathrm{P}<0.05)$ compared to those at duration of storage of 0 and 3 days. However, at the duration of 6 and 9 days of storage, the increases in total plate count and mold count were not significantly different $(\mathrm{P}>0.05)$. Total plate count ranged from $3.15 \pm 0.58 \mathrm{log} \mathrm{cfu} / \mathrm{g}$ at the time of production to $4.84 \pm 0.21 \mathrm{log} \mathrm{cfu} / \mathrm{g}$ at the storage duration of 9 days, while mold count ranged from $2.83 \pm 0.21$ $\log \mathrm{cfu} / \mathrm{g}$ at the time of production to $4.79 \pm 0.14 \log \mathrm{cfu} / \mathrm{g}$ at the storage duration of 9 days (Table 2).

\section{DISCUSSION}

\section{Characteristics of Sie Reuboh with Addition of Different Doses of Palm Vinegar (Arenga pinnata) and Kaffir Lime Leaves (Citrus hystrix)}

Tenderness. Higher concentrations of palm vinegar was associated with a lower tenderness of sie reuboh. Therefore, the tenderness of sie reuboh was better without palm vinegar and kaffir lime leaves addition during the production process. The presence of acetic acid in the palm vinegar was able to extract protein, thus weakening protein myofibril bonds in meat, reducing water content of meat, and leading to a higher meat dryness. The presence of acid contributed to the demolish of myofibril bonds, leading to a higher release of water. Cheng \& Sun (2008) reported water holding capacity of red meat. Water holding capacity of the meat protein affects physical properties of meat, including texture, cooking loss, tenderness, as well as compactness of fresh meat. Most of water is present in free molecules within myofibrils, within cavities between the thick filaments of myosin and the thin filament of actin (tropomyosin), within the muscle fibers of the flesh, and between the layers of connective tissue or between the bundles of muscle fibers.

Water activity $\left(\mathbf{a}_{\mathrm{w}}\right)$. Water activity of sie reuboh was strongly associated with moisture content, particularly free water content. $\mathrm{RH}$ (relative humidity) and $\mathrm{a}_{\mathrm{w}}$ also showed strong correlations with the moisture content of a product. Zhang et al. (2017) stated that $\mathrm{a}_{\mathrm{w}}$ correlated well with moisture contents inside the product, while $\mathrm{RH}$ correlated well with moisture contents around the product, especially free water content. In this work, the $a_{w}$ value indicated that the product was moderately moist. Water activity $\left(\mathrm{a}_{\mathrm{w}}\right)$ and moisture content of meat product having a moderate moisture were $0.60-0.90$ and $20 \%-40 \%$, respectively.

pH. The decrease in $\mathrm{pH}$ was caused by the penetration of acid components into the meat, leading to a decreased $\mathrm{pH}$ of sie reuboh. Birk et al. (2010) reported that meats that were soaked in organic acid solutions (acetic acid, citric acid, tartrate acid, lactic acid, and malate acid) had lower $\mathrm{pH}$. The $\mathrm{pH}$ of palm vinegar used in this work ranged from 3.23 to 3.25 . In addition to producing an acid taste, incorporation of acid compound also reduced $\mathrm{pH}$. This current work produced sie reuboh with a lower $\mathrm{pH}$. Based on the $\mathrm{pH}$, foods are grouped as high acid food $(<4.5)$ and low acid food (4.5-7.5). The low acid food is susceptible to spoilage and toxin-producing microorganism, thus requiring a serious handling strategy (Estiasih \& Ahmadi 2009).

Yield. Yield was affected by spices used and concentrations of fresh kaffir lime leaves as antioxidants that were not soluble in water. Sie reuboh was not incorporated by carbohydrate component in which its starch granule had capability to absorb water, as well as other components 
that have water-soluble and water-binding properties, swelling power, and high water content. Higher yield resulted in higher economical value of a product. In contrast, a lower yield was responsible for a lower economical value and effectivity of a product (Hardesty, 2008).

Total plate count (TPC). Sie reuboh was considered as an acceptable food for consumption, based on BSN No. 083-7388-2009. Microbiological requirements of processed meat in Indonesia were TPC of $10^{5} \mathrm{cfu} / \mathrm{g}$, S. aureus count of $10^{2} \mathrm{cfu} / \mathrm{g}$, and E. coli count of $<3 / \mathrm{g}$. Acidic compounds can contribute as preservative agents which inhibit microbial growth in food, including pathogenic bacteria (Arief et al., 2015). Yuliani et al. (2011) reported that essential oils contents of kaffir lime leaves could inhibit and deactivate $S$. aureus and E. coli.

\section{Characteristics of Sie Reuboh Stored at Room Temperature}

Water activity $\left(a_{w}\right)$. Enhancement of $a_{w}$ was associated with the temperature and moisture of environment during the storage of sie reuboh. Increment was resulted from addition of top water layer which was induced by storage conditions product. Relative humidity (RH) is an essential factor that directly affects $a_{w}$ Adams \& Moss (2008) state that higher absorbed water lead to the increase in $a_{w^{\prime}}$ leading to a higher susceptibility to microbial growth. On day 6 and day 9 of storage, the $a_{w}$ values were 0.855 and 0.837 until the end of storage period. On day 9 of storage, the presence of hypha growth was observed, but their contamination was not found in all samples. The decreased $a_{w}$ vlues in sie reuboh was associated with nutritional degradation, particularly protein, by microorganism, which lead to the lower water binding capacity of protein. We observed that a longer storage duration led to the decreased water binding capacity of sie reuboh as a result of microbial activity that promoted protein degradation. Microorganisms require different $\mathrm{a}_{\mathrm{w}}$ conditions for their optimum growths such as 0.88 and 0.80 for yeast and molds, respectively. Gram positive bacteria and gram negative bacteria require $\mathrm{a}_{w}$ at the levels of 0.90 and 0.93 , repectively (Adams \& Moss, 2008). Therefore, sie reuboh with a range of $\mathrm{a}_{\mathrm{w}}$ from 0.837 to 0.860 was more susceptible to mold growth.

pH. Microbial activity during storage could induce proteolysis that produced amino acids. These amino acids were then converted into simpler compounds that had base properties, contributing to the increase in $\mathrm{pH}$. The $\mathrm{pH}$ values of the sie reuboh ranged from $5.31 \pm 0.66$ to $5.86 \pm 0.33$. The experimental sie reuboh was stored at $28-31^{\circ} \mathrm{C}$, which provided desirable conditions for bacterial growth. Food with $\mathrm{pH}$ aroud 7 (almost neutral) and high water contents are susceptible to the growth of spoilage microorganisms that eventually increases the rate of food spoilage (Duarte et al. 2014).

Antioxidant capacity and antioxidant activity. Antioxidant capacity of sie reuboh was affected by the interaction between the composition and concentration of antioxidant compounds in the spices, palm vinegar, and lime leaves used during the production of sie reuboh. Antioxidant activity of sie reuboh was decrease, indicating that antioxidant compounds in sie reuboh inhibited lipid oxidation through retarding activity of free radicals during storage. Zhang et al. (2010) reported that polyphenol, flavonoid, terpene, phenolic, and tannin were responsible for antioxidant activity. Peel and leave extracts of Citrus hystrix showed a remarkable antioxidant activity. Flavonoid is a phenolic compound that shows a strong antioxidant activity (Licina et al., 2013). Palm vinegar was used to provide a sour taste and to avoid changes in color induced by oxidation. According to synergistic properties, antioxidative agent is grouped into 2 categories: high phenolic compound and high acid compound (Zhang et al., 2010). Antioxidant effect of phenolic compound is unable to scavenge oxygen, but able to retard the formation of free radicals from lipid, which react with oxygen during lipid oxidation, thus autoxidation was postponed (Pereira et al., 2009).

TBARS. Decrease in antioxidant activity was associated with the increase in TBARS. Initially, during the storage, the unique flavor of sie reuboh was strongly detected, but we found that no rancidity flavor was detectecd at the end of storage period. Lipid oxidation was occurred until the end of storage period in room temperature due to a decrease in antioxidant activity to inhibit oxidation by retardation of free radicals productions (Oliveira et al., 2011). This condition indicated lipid degradations as a result of free radical autooxidation of unsaturated fatty acids in sie reuboh that was affected by factors during storage. This condition was associated with a higher accumulation of lipid oxidation of unsaturated fatty acids in the sie reuboh. The presences of antioxidant compounds in spices, palm vinegar, and kaffir lime leaves were able to attenuate oxidation rate of unsaturated fatty acids in meat. The maximum level of TBARS in the processed meat that showed no rancidity flavor was $2.28 \mathrm{mg} \mathrm{MDA} / \mathrm{kg}$. TBARS of sie reuboh until day 9 of storage showed no rancidity flavor. Compo et al. (2006) found that TBARS of 2.28 was acceptable threshold for oxidation of rancid beef. Synergistic effects of acid and antioxidant activity retard the rancidity and browning of foods containing carbohydrate, protein, and fat or oil. Inhibition of lipid oxidation by acid was due to the capability of metal bonding. The presence of metal was able to induce initial oxidation (Oliveira et al., 2011). Retardation of MDA formation and the use of spices with antioxidant properties produce desirable effects in meat products (Li et al., 2010).

Total plate count (TPC). The addition of the palm vinegar and kaffir lime leaves could inhibit the pathogenic bacteria of sie reuboh to the level of acceptable until day 3 of storage at room temperature. According to Badan Standardisasi Nasional (BSN), Total plate count value for processed meat was $10^{5} \mathrm{cfu} / \mathrm{g}$. Al-Qadiri et al. (2008) stated that longer storage period was positively correlated with higher number of bacteria, since some nutrients were required for their growth. Schaechter (2015) stated that other factors affecting microbial growth were water 
content of media, nutrition availability, oxygen pressure, as well as $\mathrm{pH}$, and temperature of their environments. Their growth rates could be retarded by inclusion of preservative compounds that enable to maintain product quality and assure food safety (Devatkal et al., 2010). Widyaningrum et al. (2015) observed the effects of vinegar made from banana peel on chicken meat, and the result suggested that the use of this vinegar could destabilize L. monocytogenes in raw chicken meat stored in room temperature and cool storage. Total phenolic compounds are associated with antibacterial activity. Terpene compounds had been shown to have antibacterial effect through deconstruction of cell wall and inhibition of cell growth (Yuliani et al., 2011).

Mold. Mold growth was observed until the end of 9 days storage at room temperature. Mold growth is influenced by some factors including temperature (optimum growth at $25-35^{\circ} \mathrm{C}$ ), water and oxygen availabilities, $\mathrm{pH}$, and nutrition (Schaechter, 2015). Incubation at $37^{\circ} \mathrm{C}$ is the optimum condition for mold growth, but higher temperature is needed for optimum growth of yeast. Madduluri et al. (2013) reported that saponin was effective as an antifungal compound by lowering the surface tension of cell wall and promoting membrane dysfunction that caused the migration of protein and enzyme from the cytoplasm to the extracellular spaces.

\section{CONCLUSION}

Sie reuboh without addition of palm vinegar and kaffir lime leaves showed a better tenderness than sie reuboh added with palm vinegar and kaffir lime leaves. Addition of $120 \mathrm{~mL}$ of palm vinegar and $20 \mathrm{~g}$ of lime leaves (P2) was effective to maintain the quality of sie reuboh until 3 days of storage at room temperature according to microbiological standard of SNI 08-3-73882009 for processed meat and to maintain a stable TBARS value until 9 days of storage at room temperature.

\section{REFERENCES}

Adam, M.R. \& M.O. Moss. 2008. Food Microbiology. $3^{\text {rd }}$ Edition. RSC Pub., Cambridge (UK).

Al-Qadiri, H. M., N. I. Al-Alami, M. Lin., M., Al-Holy, A. G. Cavinato, \& B. A Rasco. 2008. Studying of the bacterial growth phases using fourier transform infrared spectroscopy and multivariate analysis. J. Rapid Methods Autom. Microbiol. 16: 73-89.

Arief, I.I., B.S.L. Jenie, M. Astawan, K. Fujiyama, \& A.B. Witarto. 2015. Identification and probiotic characteristics of lactic acid bacteria isolated from Indonesian local beef. Asian J. Anim. Sci. 9:25-36.

[BAM] Bacteriological Analytical Manual online. 2001. http:// www.fda.gov/food/foodscienceresearchlaboratorymethod/ucm2006949. [February 16, 2017].

[BSN] Badan Standar Nasional. 2009. Standar Nasional Indonesia (SNI) No. 08.373882009 tentang Batas Maksimum Cemaran Mikroba dalam Pangan, Jakarta.

Birk, T., A.C. Gronlund, B.B. Christensen, S. Knochel, K. Lohse, \& H. Rosenquist. 2010. Effect of organic acids and marination ingredients on the survival of Campylobacter jejuni on meat. J. Food Protect. 73: 258-265. https://doi. org/10.4315/0362-028X-73.2.258
Campo, M. M., G. R. Nute, S. I. Hughes, M. Enser, J. D. Wood, \& R. I. Richardson. 2006. Flavour perception of oxidation in beef. J Meat Science 72:303-311. http://dx.doi.10.1016/j. meatsci.2005.07.015.

Cheng, Q \& D. Sun. 2008. Factors affecting the water holding capacity of red meat products: a review of recent research advances. Crit. Rev. Food Sci. Nutr. 48:137-159.

Devatkal, S. K. \& B. M. Naveena. 2010. Effect of salt, kinnow and pomegranate fruit by product powders on color and oxidative stability of raw ground goat meat 358 during refrigerated storage. Meat Sci. 85: 306-311. 359 http:// dx.doi.10.1016/j.meatsci.2010.01.019.

Duarte, R. V., S. A. Moreira, P. A. R. Fernandes, L. G. Fidalgo, M. D. Santos, R. P. Queirós, \& J. A. Saraiva. 2014. Preservation under pressure (hyperbaric storage) at 25 ${ }^{\circ} \mathrm{C}, 30^{\circ} \mathrm{C}$ and $37^{\circ} \mathrm{C}$ of a highly perishable dairy food and comparison with refrigeration. CyTA-Journal of Food 13:321-328.

Estiasih, T. \& K. G. D. Ahmadi. 2009. Teknologi Pengolahan Pangan. Cetakan Pertama. Penerbit Bumi Aksara, Jakarta.

Hardesty, S. D. 2008. The growing role of local food markets. Am. J. Agric. Econ. 90: 1289-1295.

Li, Z., S. Henning, M. Y. Zhang, A. Zerlin, L. Li, K. Gao, R. P. Lee, H. Karp, G. Thames, S. Bowerman, \& H. Heber. 2010. Antioxidant-rich spice added to hamburger meat during cooking results in reduced meat, plasma, and urine malondialdehyde concentrations. J Clin. Nutr. 91: 1180-1184.

Licina, B. Z., O. D. Stefanovic, S. M. Vasic, I. D. Radojevic, M. S. Dekic, \& L. R. Comic. 2013. Biological activities of the extracts from wild growing Origanum vulgarel. J. Food Control. 33: 498-504. http://dx.doi.org/10.1016/j. foodcont.2013.03.020.

Mani-López, E., H. S. García, \& A. López-Malo. 2012. Organic acids as antimicrobial to control salmonella in meat and poultry products. Food Res. Int. 45: 713-721. http:// dx.doi:10.1016/j.foodres.2011.04.043.

Madduluri, S., K.B. Rao, \& B. Sitaram. 2013. In vitro evaluation of antibacterial activity of five indigenous plants extract against five bacterial pathogens of human. Int. J. Pharm. Pharm. Sci. 5:679-684.

Oliveira, C.M., A.C.S. Ferreira, V.D. Freitas, \& A.M.S. Silva. 2011. Oxidation mechanisms occurring in wines. Food Res. Int. 44: 1115-1126.

Pereira, A. L. F., T. F. Vidal., M. C., Teixeira, P. F. Oliveir, R. C. F. Pompeu, M. M. Vieira, \& J. F. F. Zapata. 2009. Antioksidant effect of mango seed extract and butylated hydroxytoluene in bologna-type mortadella during storage. Food Science and Technology (Campinas). 31: 135-140.

Rahmi, U., M. Yunazar, \& S. Adlis. 2013. Profil fitokimia metabolit sekunder dan uji aktivitas antioksidan tanaman jeruk purut (Citrus histrix DC) dan jeruk bali (Citrus maxima Merr). J Kimia Unand. 2:109-114.

Schaechter, M. 2015. A brief history of bacterial growth physiology. Front. Microbiol. (6): article 289. https://doi. org/10.3389/fmicb.2015.00289

Sorensen, G. \& S. S. Jorgensen. 1996. A critical examination of some experimental variables in the 2-thiobarbituric acid (TBA) test for lipid oxidation in meat products. Zeitschrift fur Lebensmittel Untersuchung und Forschung. 202: 205-210.

Tangkanakul, P., P. Auttaviboonkul, B. Niyomwit, N. Lowvitoon, P. Charoenthamawat, \& G. Trakoontivakorn. 2009. Antioxidant capacity, total phenolic content and nutritional composition of Asian foods after thermal trocessing. International Food Research Journal. 16: 571-580.

Theron, M. M. \& J. F. R. Lues. 2007. Organic acids and meat preservation: A review. Food Reviews International. 23: 141-158. http://dx.doi10.1080/87559120701224964. 
Widaningrum, Miskiyah, \& Juniawati. 2015. Efikasi cuka kulit pisang dan air kelapa sebgai penghambat Listeria monocytogenes pada daging ayam. J. Penelitian Pascapanen Pertanian. 12: 43-54

Yuliani, R., P. Indrayudha, \& S. S. Rahmi. 2011. Antibacterial activity of volatil oil of small aromatic lemon leves (Citrus hystrix) against Staphylococcus aureus and Escherichia coli. Phaermacon 12: 50-54.
Zhang, W., S. Xiao, H. Samaraweera, E. J. Lee, \& D. U. Ahn. 2010. Improving functional value of meat products. Meat Sci. 86: 15-31. http://dx.doi:10.1016/j.meatsci.2010.04.018

Zhang, L., D. Sun, \& Z. Zhang. 2017. Methods for measuring water activity (aw) of foods and its applications to moisture sorption isotherm studies. Crit. Rev. Food Sci. Nutr. 57: 1052-1058. http://dx.doi.org/10.1080/10408398.2015.11 08282 